\title{
O livro dos tempos: \\ um percurso pessoal
}

\author{
Jacó Guinsburg
}

JACÓ GUINSBURG é professor de

Estética Teatral do Departamento de Artes Cênicas da ECA/USP e da pós-graduação em Estudos Judaicos na área de Hebraico do Departamento de Línguas Orientais da FFLCH da USP. É autor de

"Stanislavski e o Teatro de Arte de Moscou" (Perspectiva) e "Leone De' Sommi, um judeu no teatro da renascença italiana" (a sair pela Perspectiva).
Este encontro pede-nos que falemos de nossa relação com a Bíblia em termos de uma experiência pessoal e literária. A idéia de experiência exige que submetamos o nosso discurso a um mínimo de tratamento crítico e que tentemos relatá-lo como vivências tão autênticas quanto possiveis e quanto pode permitir qualquer apreensão humana de fatos vividos, experimentados e inscritos no registro da memória com um sinal que possa ser ativado em nosso prosseguimento no tempo.

Por isso mesmo, de minha parte, creio ser necessário começar por alguns elementos de minha história de vida.

Embora nascido na Bessarábia e emigrado para a América do Sul aos 3 anos de idade, não creio que deva me considerar produto do ambiente e das condiçōes do schtetl judeu. Meus pais, sim. Eu, não. Nunca freqüentei um heder ou uma ieschivá. Cresci à margem da prática religiosa. Nasci em um momento em que, após a Primeira Guerra Mundial, os processos de secularização já haviam cavado fundo e produzido efeitos que já tinham afetado o modo de existência de várias gerações de judeus, inclusive a de meus pais, e que a história, a economia e a sociologia registraram cataclismicamente ao mesmo tempo que a literatura, o teatro e as artes.

Tudo isso vale dizer que meu contato com o universo judeu produziu-se, por mais que eu remonte em minha consciência e memória, no pais e no contexto em que vivo há mais de sessenta anos.

Filho de emigrantes, emigrante eu mesmo, cresci em um bairro da emigração, o BomRetiro paulistano. A minha educação foi apenas parcialmente judaica, no sentido estrito do termo. $\mathrm{Na}$ luta pela sobrevivência, meus pais não tiveram sequer tempo para me inculcar, de modo mais sistemático, nem aquelas crenças que julgavam respeitar. Ainda que guardassem dos dias festivos e convivessem com outros judeus que faziam o mesmo, faltava a tudo isso uma aura mais densa, que me fosse sensível. Se, ao lado da Escola Pública brasileira, freqüentei por algum tempo uma Escola Judaica, pessoalmente não me lembro de ter trazido desta nenhum ensinamento mais marcante. Entrevejo apenas, talvez como lembrança, um remoto brilho de um Midrasch Agádico contado em classe. Creio ser a história do Rei Davi recontada por Bialik. Mas disto sei agora e só hoje sou capaz de identificar esta luz muito antiga na minha memória, se é que não estou confundindo lembranças. De todo modo, a impressão que me marcou, ou que atribuo àquele momento de recepção, foi a do brilho de um rei-Messias e de uma expectativa de transformação, que talvez estivessem ligados não apenas com o que ouvia à minha volta, nas conversas de meus pais e de nossos amigos, judeus como nós, sobre a vida judaica em outras partes, sobretudo in der heim, no mundo europeu oriental, mas também à esperança de transformar as árduas condições em que nós mesmos vivíamos, numa terra diferente, com uma língua que, embora já então totalmente adquirida por mim, era, não obstante, diferente dos sons e das inflexōes que soavam no mais íntimo do que estava ao meu redor.

Esta estranheza que povoou minha infância, aliás, não impedia que concomitantemente Jesus de Nazaré fosse para mim uma figura bastante atrativa e que, às vezes, mesmo se 
os garotos cristãos malhassem o Judas no sábado de Aleluia, eu não me sentisse atraído por suas mercês e as de Nossa Senhora, especialmente quando ficava ofuscado pelos interiores das igrejas e pelos cânticos das procissões ou pela alegria das quermesses cristãs.

$\mathrm{Na}$ minha casa, como em outras casas judaicas, o estudo era um valor e uma promessa de ascensão econômica e social, de modo que, desde cedo, fui posto a cursar escolas para realizar o sonho do diploma. Mas, até certo ponto, acontecia comigo como no conhecido conto de Isaac Babel: eu era obrigado a ir aprender a tocar violino quando o que eu queria mesmo era ir à praia. De minha parte, porém, conseguia vingar-me. Largava a álgebra e a gramática abandonadas no livro não-aberto e me entregava apaixonadamente à literatura de ficção e à História. E entre as duas não deixava de voar pelo espaço interestelar com os quadrinhos de Flash Gordon. Das muitas coisas que povoavam este meu universo, nenhuma certamente dizia respeito ao Judaísmo. Se sobrava algum canto era para César e não para Isaías.

A bem dizer, pois, o contato mais antigo e efetivo com o texto biblico judaico de que tenho consciência se verificou na época de meu bar-mitzvá. Não creio que eu tenha retido grandes porçōes do Humasch (Pentateuco) nem dos Profetas. Um norne que ressoa ainda nos meus ouvidos, como que vindo deste período de minha iniciação, é o de Moisés. É possível que ele, na verdade, esteja ai a ecoar mais por causa do Pessach e da saída do Egito. Mas, de todo modo, é do alto de sua envergadura no confronto com o Faraó, e de seu poder de galvanização das energias de um bando de escravos, que ele assoma em minha memória no cimo do Sinai. Daí o desapontamento que julgo me terem causado as suas limitaçōes, principalmente aquelas a que teria sido obrigado a curvar-se por uma vontade mais poderosa.

Conservo esse travo de frustração a invadir-me quando, ao fim de um esforço quase sobre-humano, o emissário divino recebia, em recompensa, como por ironia, a rebelião pagã do povo prosternado, ante seus olhos estupefatos, ao pé dos ídolos ou dançando em orgia à sua volta. $E$, mais ainda, se é que a tão longa distância isto corresponde a algo real, quando Moisés após tão inauditas realizações era castigado, por causa de um breve momento de ira, com uma espécie de ingratidão divina, para mim, sendo-lhe permitido apenas vislumbrar a Terra Prometida. Não me parecia justo.

Mas, ainda assim, a sua figura permaneceu na minha imaginação como a de um ser inteiro e fundante com o qual uma parte do que eu era tinha uma relação intrínseca que me dava algo de inominável, mas que me dava também uma justificação para o meu nome, em meio de tantos outros.

Os anos do fascismo virulento, do hitlerismo, do integralismo brasileiro e da ditadura do Estado Novo foram os de minha passagem da adolescência para a mocidade. Apesar do antisemitismo, às vezes declarado, e que, nas suas diferentes versōes, ocupava constantemente as colunas dos jornais com manifestações em toda a parte, inclusive no Brasil, a presença judaica no ambiente em que eu cresci, fora da coletividade, não era tão marcante a ponto de ser um alvo constante no trato cotidiano das marginalizaçōes, discriminaçōes e agressões que pareciam ameaçá-la.

Dai porque, em que pese um arranhão de não-pertinência e estranheza, às vezes identificadas mas não fixadas, as inquietações, os sonhos e as buscas de um jovem podiam aqui abrir-se para horizontes mais amplos, que talvez contivessem traços de sua condição judaica, mas que não deveriam necessariamente expressar-se em termos específicos. A miséria, a opressão e a espoliação eram universais, sendo palpáveis em toda a parte e não menos na realidade brasileira. Os movimentos e as lutas que se desenvolviam para modificar no país esta situação falavam-me pois com uma voz que calava no fundo de mim. O universo da esquerda militante tinha um apelo que parecia compreender tudo na sua promessa de libertação, inclusive aquela minha ponta de desajuste que não se encaixava em parte alguma.

Foi na militância política que, entre tantas outras coisas, cruzei com a mensagem social e utópica do profetismo judeu. Não foi propriamente a Bỉlia que ma distinguiu e sim Max Beer, Kalman Marmar, Kautstky e outros, sob as barbas proféticas de Marx e Engels. A partir de suas pregaçōes, Amós e Isaías passaram a projetar, para mim, a sua ética da justiça social-religiosa e da redenção escatológica do oprimido, mas num plano nada celestial nem transcendente. Pois, ali estava uma expressão típica, a meu ver de então, no plano concreto da realidade terrena, da luta de classes e do processo dialético da história, tal como o materialismo marxista o encarava e que, sem forçar a mão, iluminava também algumas sombras que ainda permaneciam dentro de mim, e que apesar de tudo ainda me provocavam de vez em quando uma malaise, empanando a visão radiante e eufórica do u-topos.

Os fatos brutais da Segunda Grande Guerra, principalmente em relação aos judeus, começaram a estourar como bombas nas consciências, mesmo quando bem abrigadas sob uma 
proteção qualquer, ideológica, política, econômica ou social e a arrancar do fundo de si mesmas até aquelas que lá estavam entocadas como ratos. Não era possível escapar às monstruosas evidências que se precipitavam sobre cada um de nós, dia a dia. Um sentimento de trágico abandono, de impotência, de uma loucura assassina, totalmente fora de quaisquer padrōes humanos de explicação, ia amontoando-se, como as montanhas de ossos e bonecas quebradas, à medida mesma que a barbárie recuava e se desvendava ante a força do que grosso modo podia parecer o poder da liberdade e da justiça, da razão e do significado do homem. Dentre os escombros e o holocausto da vida judaica, das cinzas, das valas e dos crematórios começaram a filtrar-se então duas pequenas chamas de início que se fizeram crescentemente dois chamados: o gueto de Varsóvia e Israel redivivo. Uma coisa tornava-se com o passar dos meses cada vez mais vinculada à outra, mesmo para quem, e não eram poucos, os desvinculava ideológica e politicamente. A relação que se estabelecia então entre ambas trazia à minha mente uma sugestão que tinha um atrativo de visão: não só a do Apocalipse como a do Messias. Havia algo de escatológico - messiânico na forma como aquilo que fora esmagado se enformava como renascimento. Isaías, o segundo Isaías, Jeremias e Daniel o haviam acalentado do fundo da história judaica. E aqui estava a sua palavra numa nova articulação a enunciar-se novamente. Mas a meus ouvidos, a sua anunciação renovadora e redentora tinha o timbre não do enviado dos céus, porém de Judá Macabeu.

A nova postura que se desenhava no meu espírito recebeu precisamente então um conteúdo mais concreto devido à intervenção, me parece hoje, de dois fatores, ambos estreitamente conectados entre si. O primeiro foi que o meu interesse pelos livros se converteu em um projeto de os produzir e editar e o segundo, que talvez tenha antecedido o primeiro, foi que este propósito, que já era uma espécie de programa, concedia um espaço especial à herança cultural judaica, tanto é que se consubstanciou na publicação, em 1948, de uma Antologia Judaica.

O curioso neste empreendimento é que eu tinha dois companheiros, que não eram judeus, e que, no entanto, advogavam ardorosamente o desenvolvimento deste programa de edição: a divulgação em língua portuguesa das grandes produçōes das letras e do pensamento judaicos. O motivo que os impelia era, pelo lado não-judeu, bastante parecido ao meu, pelo lado judeu. Brotava, quer me parecer, do clima que no fim da década de 40 prevalecia no meio intelectual brasileiro e de uma comunhão de pontos de vista filosóficos e políticos.

Seja como for, a verdade é que para dar cabo da tarefa eu e Carlos Ortiz, um de meus companheiros de trabalho, tivemos de mergulhar no repositório das tradições e das realizações da cultura da grei de Israel. De minha parte não pude mais, desde então, me desvencilhar deste universo, apesar de estar constantemente envolvido em outros dominios, dentre os quais o teatro e, em particular, a literatura brasileira não foram de menor peso.

Mas, devo dizer que na época em que se intensificou minha relação com o judaísmo, que era exatamente a do surgimento do Estado de Israel, eu estava particularmente voltado para a literatura ídiche, em cujas páginas absorvi muitas reelaboraçōes do versículo bíblico. De Mêndele, Scholem Aleihem e Peretz até Singer, Opatoschu, Der Nister e Bergelson percorri uma prodigiosa sucessão de cruzamentos entre a Escritura e a escritura que correspondia na seqüência do tempo a outras tantas captações e eventualmente releituras do saber, das experiências e do imaginário bíblicos. Schir ha - Schirim adquiriu na minha emoção e imaginação os contornos de ESTER LIBE, dai LIBUSE e depois BUSE com SCHIMEK na prosódia lírica da narrativa de Scholem Aleihem; na minha razão o verbo flagelante de Mêndele transmutou os cantares salomônicos em um símile talmúdico das desgraças do povo de Cabtzansk; Peretz e Asch me recontavam com novas palavras de uma arte, poeticizada nos relatos hassídicos e populares do primeiro e epicizada nos romances históricos do segundo, a reencarnação moderna das personagens e dos temas que estavam gravados no Livro e na herança de seu povo.

Não obstante, naquele momento mesmo, talvez pela tentação da crítica e pela busca do contraditório como recursos de análise do estabelecido, comecei a interessar-me especialmente pelas rebeliões, pelas heterodoxias e pelos movimentos messiânicos no seio do judaísmo que, desbordando as páginas do cânone, crispavam os livros apócrifos e apocalipticos. O problema histórico, político e religioso que se vestia em seus ideologemas me instigava quer pela forma como eram produzidos, quer por suas conseqüências. Mais do que isso, porém, me importava o fator de ativismo político e revolucionário que eles continham. E foi com grande sintonia de espírito que traduzi o livro de Howard Fast, "Os Meus Gloriosos Irmãos".

É claro que no jogo de sentimentos e de idéias que tentei caracterizar mais acima havia em relação ao texto bíblico, tanto quanto a admiração pelas relações que me proporcionava, a perplexidade pelas dúvidas que não aclarava. Na trilha oblíqua destas incertezas, encontrei os indicadores furta-cores da ironia. A tetralogia de Thomas Mann sobre José e Seus Irmãos me jogou por essa via no poço bíblico da história. 


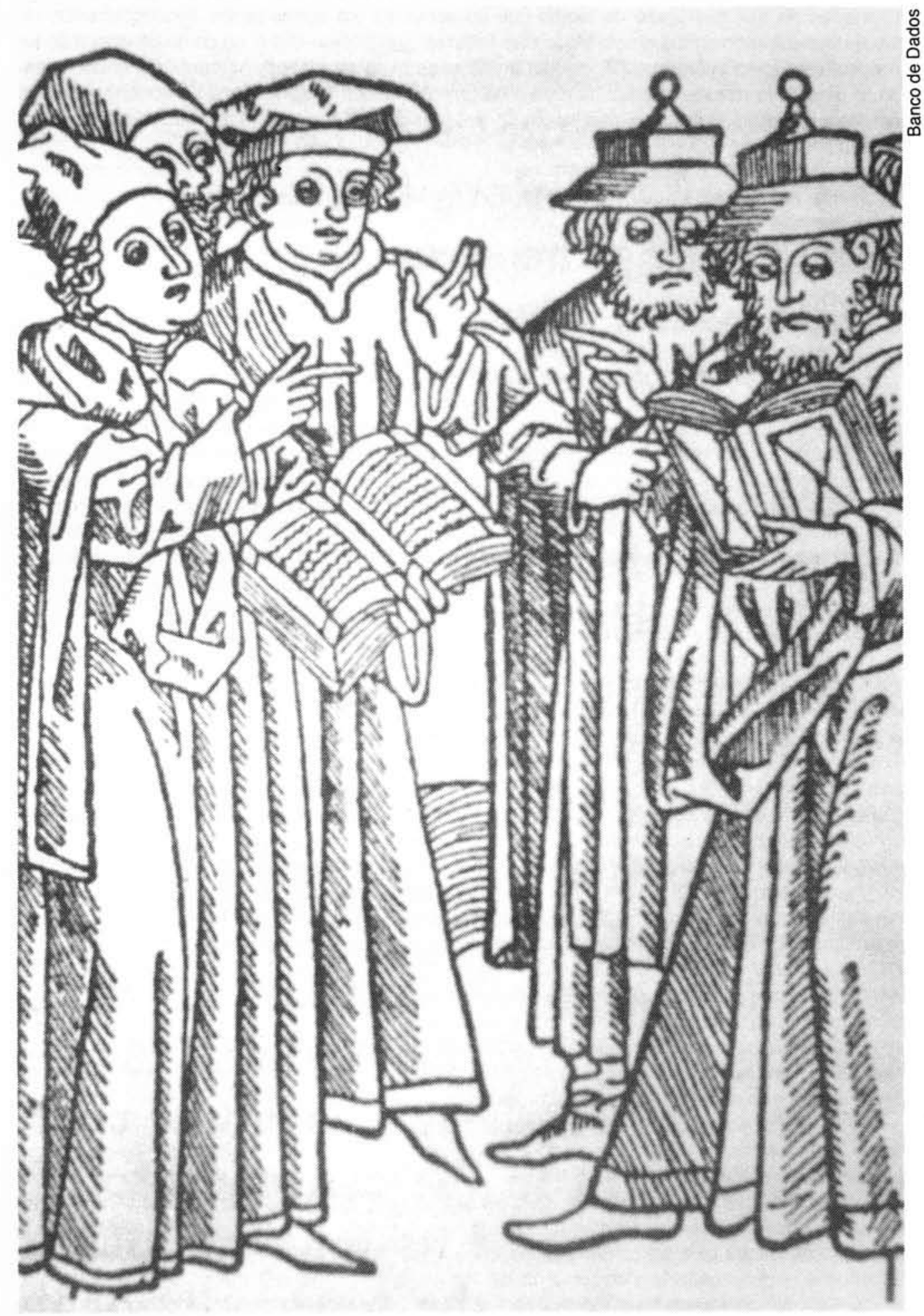

Gravura representando uma disputa religiosa entre rabinos e padres no século XVI 
O remontar pelo oco do passado começou a decompor estroboscopicamente a precisão histórica, política e religiosa dos episódios e das figuras até aqui claramente singularizadas e firmemente embasadas no terreno positivo das realidades e localizaçōes espaço-temporais. Abraão, Isaac, Esaú, Jacó, as Matriacas, os doze filhos de Israel e particularmente José começaram a perder as suas unidades individuais e a manifestar uma multiplicidade de figurações e metamorfoses na sucessividade do tempo que os convertia em outros tantos desdobramentos do mito e da lenda recontados e sobretudo das fissuras exegéticas, isto é, do ponto de vista e do foco escolhidos pelo intérprete. Não perderam as suas exemplaridades. Ao contrário, estas galgavam a uma nova altitude que era de uma estruturação menos simplificada e particularizada, mais complexa e múltipla, e por isso mesmo capaz de abranger um espectro mais amplo da experiência humana.

O presente adentrava-se e intervinha nas suas expressões com o mesmo direito que o passado, na medida em que era um de seus componentes básicos, aquele que fornecia o substrato existencial das representações, ou melhor, das representificações. Graças a isto podia-se realizar o reconhecimento daquilo que foi como sendo ainda o que é. José continuava, modelarmente, sendo aquele que sai para vir a ser, ao mesmo tempo que projetava aquele que é atualmente como tendo sido aquele que foi, o que via aquilo que iria ver, porém não necessariamente aquilo deveria ver. Isto implicava na sua liberdade em face da determinação divina, mas não o isentava da inexorabilidade da sua destinação.

Naturalmente, este movimento remissivo das significações, esta reflexividade das criaturas que saem de si para poderem entrar em si, esta relativização dos lugares na busca do absoluto e esta dialogização das palavras enquanto vozes do verbo divino, recortava a escrita testamentária em um mosaico de incisões problemáticas e indagações críticas e transformava o tratamento irônico no principal instrumento de investigação da arqueologia das verdades bíblicas.

Um trabalho meu escrito àquela altura aborda o tema de "A Mulher na Bíblia" com semelhante enfoque. A tentativa era a de mascarar parodisticamente personagens e incidentes que se adequavam aos meus propósitos e jogar a letra dos versículos envolvidos contra significados capazes de produzir, por contragolpe irônico, significações filosóficas e humanas inerentes mas não explícitas. Assim, eu comecei a composição com um preâmbulo que pretendia estar aderido à tradição judaica, segundo a qual tudo está dito e contido no escrito da Torá, e depois me empenhei em desenvolver a narrativa logicamente, até certo ponto em oposição, com elementos colhidos entre versículos consecutivos, na senda agádica ou haláhica. $\mathrm{O}$ objetivo era questionar a visão tradicional sobre a mulher e o feminino. Dai o leit-motiv adotado: o da ajuda prestada pela mulher ao homem. Por exemplo, lê-se no relato Eva, a ajudadora:

"Deus fez a Criação e viu que era realmente uma beleza. Tudo funcionava. Ficou tão satisfeito com sua obra-prima que julgou não poder reservar-se a sua contemplação. Afinal de contas, não precisava daquilo para ver, dentro de si, sem sair de sua infinitude, as maravilhas que quisesse. Já que se dera ao trabalho, o Artista achou que deveria expor a sua Criação aos olhos de alguém mais: um espectador, uma testemunha. Só assim ela se completaria, adquiriria um sentido específico, um fim. Ora, é claro que este apreciador, para formar uma imagem, para 'enxergar' o que fora realizado, precisaria dispor de atributos que só o Criador tinha até então. Por isso Deus disse: 'Façamos o homem à nossa imagem conforme a nossa semelhança'. Dito e feito".

"Mas quem conhece os caminhos do Criador? Ele dotou a criatura generosamente. Deu-lhe todos os meios de sentir, discernir e mesmo escolher, por arbítrio próprio. Tornou o homem um contemplador ideal e o instalou no meio das maravilhas do Éden. Mas se pretendia que ele continuasse nesse estado, por que plantou no centro do Jardim a árvore do bem e do mal? E mais ainda: por que achou necessário dar a Adão uma companheira? e permitiu que a serpente viesse a saber do segredo da árvore e da mulher?"

"Por tudo isso, é bastante provável que alimentasse algum propósito ulterior, e não inteiramente expresso, ao considerar que: 'Não é bom que o homem esteja só: far-lhe-ei uma ajudadora que the seja idônea' (Gên., 2, 18)."

Mas, se naquele momento não se tratava para mim apenas de seguir a trilha das lancetadas críticas na visão tradicionalista ou de adotar a negatividade de uma hermenêutica cética, ainda que escoltada pela lógica das razões, o convívio com ambas e a reflexão intermitente a seu respeito me permitiu encarar o discurso bíblico com maior equilibrio intelectual.

As contemplações radiosas e entusiásticas foram, assim, aos poucos, substituídas por uma captação de receptor analítico. Creio que esta nova relação tenha nascido também de uma necessidade de trabalho. Pois eu estava então envolvido em um projeto de publicar uma Judaica em treze volumes. O meu móvel era proporcionar ao leitor de língua portuguesa contato direto com algumas das principais expressões da criatividade judaica. Coletâneas de Agadot, do folclore da Dispersão, da elaboração religiosa e filosófica, escritos do movimento social e nacional, 


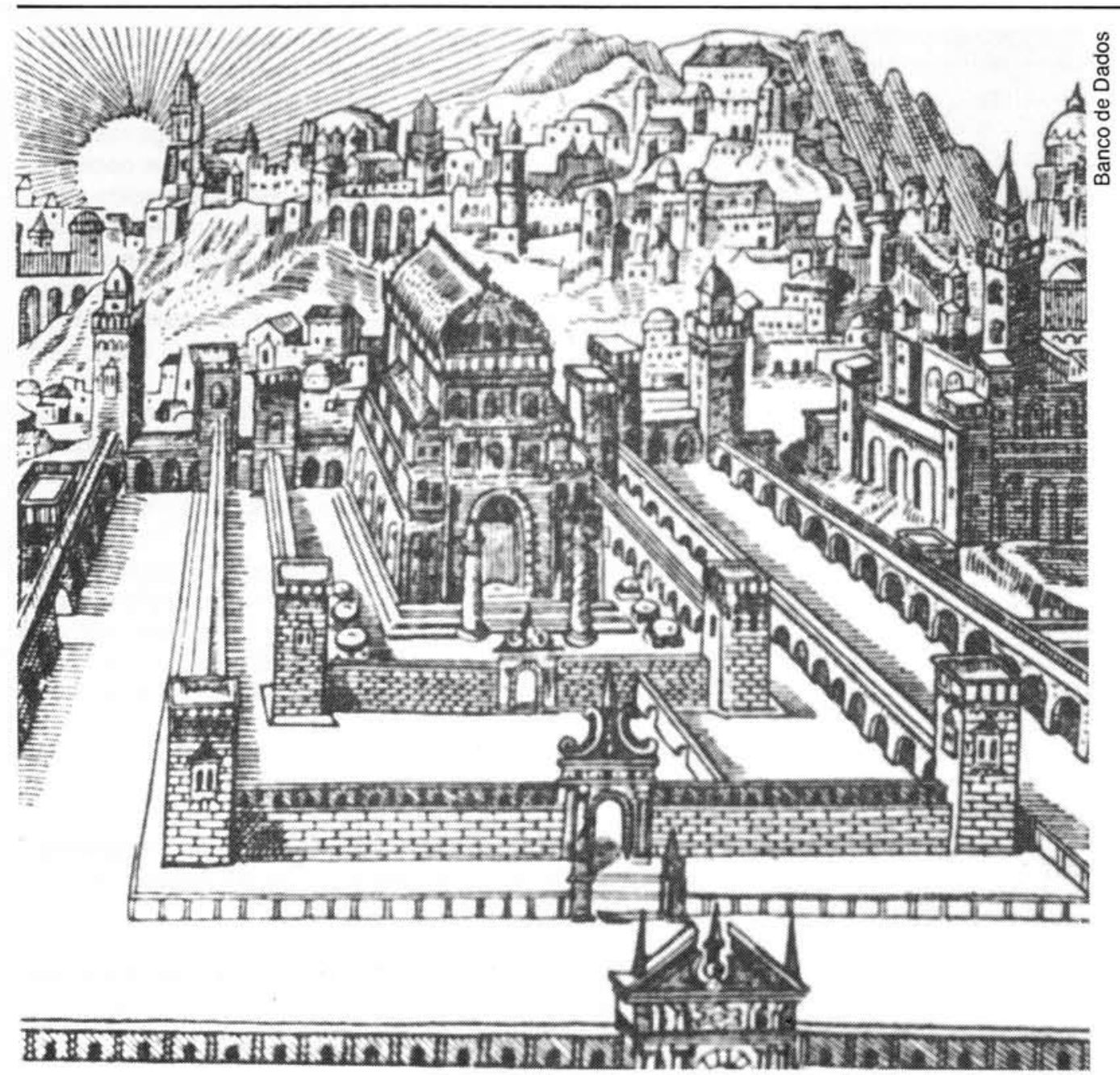

bem como das idéias mais recentes sobre o judeu e a modernidade, além dos clássicos das letras em ídiche e em hebraico, na narrativa e na poesia, deviam compor esse conjunto acompanhado sempre, em cada item, de estudos meus ou em parceria, ou de ensaios críticos de outros autores. Ao selecioná-los, procurava ampliar o meu espectro por critérios que não estivessem apenas adstritos aos já consagrados, tendo em vista o quanto eu estava distanciado das adesōes a linhas de interpretação demasiado estritas ou ideologizadas. Parecia-me que deveria abrir ao leitor um largo leque, de modo que os transcritos e minhas introduções Ihe proporcionassem a amplitude do universo de pensamentos envolvidos e, ao mesmo tempo, a relatividade das idéias - força que Ihes era afixada, bem como a sua porosidade aos influxos das relaçōes contextuais.

Todavia, vendo com os olhos de hoje o livro III desta minha Judaica, intitulado Do Estudo e Da Oração, que procura traçar o percurso do pensamento judeu desde os Profetas até o século XVII e que reservava, por certo, largo espaço também às marginálias bíblicas, isto é, aos textos não-canônicos, percebo que, na verdade, não consegui escapar totalmente da rede de concepções que haviam estruturado a minha formação e que, embora lastreadas a posteriori por ditames críticos, estavam fortemente arraigadas em critérios conteudísticos e historicistas.

Em contrapartida, devo dizer que foi em função do conjunto deste empreendimento que tive a oportunidade de me familiarizar mais com a literatura hebraica. Anteriormente, eu já havia traduzido Bialik e contistas israelenses. Mas eram trabalhos esporádicos. Agora via-me obrigado a enfrentar, afora textos filosóficos como os de Krochmal, ou a ensaística de Ahad Haam, por exemplo, obras como as de Mapu, Brenner ou Agnon, na prosa, e Gordon, Tchernihovski, Schlonski ou Guilboa, na poesia. Neste confronto mais sistemático do árduo corpo-a-corpo das línguas com a linguagem, vi-me novamente, e de outra maneira, diante da paisagem bíblica. Ela e as vozes que ressoavam de dentro de suas entranhas em mil ecos, em uma fala dos tempos e em uma reencarnação dos seres, história e espírito feito verbos, a reverberar da gruta do passado para os horizontes de hoje, devolviam-me a palavra biblica numa concretitude, surpreendente para mim.
Gravura extraída da "Haggadah" de Amsterdam (1695) mostrando uma reconstrução hipotética do Templo de Jerusalém 
A partir desta moderna estruturação articulada na dura prosódia sefárdica e ainda mais duras realidades da vida israelense de hoje, que pude sentir de perto nas minhas várias visitas à Terra, o legado bíblico, na sua fabulosa variedade e nos grandes livros, começou a assumir para mim uma feição inesperadamente renovada. Não era mais a remota herança literária de coisas vividas em mundos em que nem eu nem nenhum dos meus contemporâneos poderia ter qualquer outra experiência exceto a intelectual. $O$ presente fecundara $o$ ermo ressequido de ossos, na expressão de Bialik, o cemitério da memória histórica, restituindo-Ihes a carnação viva de uma vivência atual. Não apenas seiva vinda da raiz, mas tecido orgânico da moderna escritura poética hebraica, o versículo e a estrofe bíblicos deixaram para trás, a meus olhos, a fantasmagórica luminescência de "Sôbolos rios que vão" por todas as diásporas, que os acompanham por dois milênios e, linguagem adâmica repristinada nas tormentosas e turvas águas de Babel, pareceram-me repotenciar-se na sua expressividade.

De outra parte, quero crer, que tenham se alçado com esse estro a uma nova universalidade, reconquista e transcendência do verbo pela linguagem, e as suas constelações sígnicas e estruturaçōes semânticas se me afiguram, hoje, capazes de incorporar, conotar, simbolizar e alegorizar, na intertextualização e dialogização do passado com o presente, as formas e os ritmos, as imagens e os temas, os problemas e os conflitos da modernidade.

Assim, o Kohelet, como me revelou o poeta Haroldo de Campos na sua criativa tradução para o português, pode, para o receptor de hoje, exercer a plenitude de sua função poética e comunicar a complexa gama, quase nietzscheana, de perplexidade e angústia daquele que sabe que não sabe. Também o Gênese veio assombrar-me no transcrito deste poeta, com a súbita fulguração cabalística do Ein-Sof a lançar-se pelo cosmos criado no mallarmaico lance de dados da linguagem - escritura do Criador.

Diante destes renascimentos miraculosos do poder da linguagem das Escrituras, fico a perguntar-me, na verdade, se não é possivel concluir que a Bỉblia contém, não apenas um tempo de linguagem, mas a linguagem do tempo.

Aqui, porém, me detenho no limiar do infinito escrever-se da Escritura e do finito inscrever-se de minhas transcrições, que são leituras ao acaso feitas no Livro por um leitor judeu na América do Sul.

Agosto de 1988

\section{GLOSSÁRIO}

SCHTETL: cidadezinha, aldeia em ídiche. Designa especificamente os pequenos aglomerados urbanos em que, durante largo período, viveram os judeus da Europa Oriental.

HEDER: lit. quarto, câmara. Denominação da escola de primeiras letras no sistema educacional religioso que vigorou entre os judeus.

IESCHIVÁ: escola ou seminário rabínicos, academia talmúdica, escola de estudos judaicos superiores.

MIDRASCH: interpretação em forma de parábola de um versículo da Bỉblia. PI.

MIDRASCHIM: comentários homiléticos da Escritura baseados na HALAHÁ e AGADÁ.

AGADÁ (pl. AGADOT): lit. história, legenda, conjunto do folclore, parábolas e lendas contidas no Talmud.

TALMUD: é o mais famoso livro judaico, depois da Bỉblia. Trata-se de uma compilação de escritos, de diferentes épocas, sobre inúmeros temas, feita por intérpretes da Bỉblia e da Lei Oral.

AGÁDICO: de AGADÁ.

IN DER HEIM: lit. "em casa", em ídiche.

BAR-MITZVÁ: lit. filho do mandamento. Denominação dada ao rapaz judeu ao completar 13 anos, quando ingressa na maioridade religiosa, tornando-se responsável perante Deus.

PESSACH: Páscoa hebraica, festa da liberdade, da saída dos judeus do Egito.

SCHIR HA-SCHIRIM: Cântico dos Cânticos, em hebraico.

ESTER LIBE: lit. Ester Querida, em ídiche.

TORÁ: lit. Lei. Designa ora a Bîblia, ora a Bîblia e o Talmud juntos.

HALÁHICO: de HALAHÁ.

HALAHÁ: usado no sentido de guia, tradição prática, regra, lei. Opõe-se a AGADÁ.

KOHELET: Eclesiastes, em hebraico.

EIN-SOF: lit. Sem Fim, em hebraico. 